\title{
Responses of Benthic Macroinvertebrate Communities of Two Tropical, High-Mountain Lakes to Climate Change and Deacidification
}

\author{
Javier Alcocer ${ }^{1, *(D)}$, Luis A. Oseguera ${ }^{1}$ (D), Diana Ibarra-Morales ${ }^{2}$, Elva Escobar ${ }^{3}$ and Lucero García-Cid ${ }^{4}$ \\ 1 Grupo de Investigación en Limnología Tropical, Facultad de Estudios Superiores Iztacala, \\ Universidad Nacional Autónoma de México, Av. de los Barrios No. 1, Los Reyes Iztacala, \\ 54090 Tlalnepantla, Mexico; loseguera@unam.mx \\ 2 Posgrado en Ciencias del Mar y Limnología, Universidad Nacional Autónoma de México, Av. Ciudad \\ Universitaria 3000, Alcaldía Coyoacán, C.P., 04510 Ciudad de México, Mexico; melanosim@hotmail.com \\ 3 Laboratorio de Biodiversidad y Macroecología, Instituto de Ciencias del Mar y Limnología, \\ Universidad Nacional Autónoma de México, Av. Ciudad Universitaria 3000, Alcaldía Coyoacán, C.P., \\ 04510 Ciudad de México, Mexico; escobri@cmarl.unam.mx \\ 4 Facultad de Ciencias, Universidad Nacional Autónoma de México, Av. Ciudad Universitaria 3000, \\ Alcaldía Coyoacán, C.P., 04510 Ciudad de México, Mexico; lucero-cid@ciencias.unam.mx \\ * Correspondence: jalcocer@unam.mx
}

check for

updates

Citation: Alcocer, J.; Oseguera, L.A.; Ibarra-Morales, D.; Escobar, E.;

García-Cid, L. Responses of Benthic Macroinvertebrate Communities of Two Tropical, High-Mountain Lakes to Climate Change and Deacidification. Diversity 2021, 13, 243. https://doi.org/10.3390/ d13060243

Academic Editors: Karl Cottenie and Paolo Pastorino

Received: 29 April 2021

Accepted: 28 May 2021

Published: 31 May 2021

Publisher's Note: MDPI stays neutra with regard to jurisdictional claims in published maps and institutional affiliations.

Copyright: (c) 2021 by the authors. Licensee MDPI, Basel, Switzerland. This article is an open access article distributed under the terms and conditions of the Creative Commons Attribution (CC BY) license (https:// creativecommons.org/licenses/by/ $4.0 /)$
Abstract: High-mountain lakes are among the most comparable ecosystems globally and recognized sentinels of global change. The present study pursued to identify how the benthic macroinvertebrates (BMI) communities of two tropical, high mountain lakes, El Sol and La Luna, Central Mexico, have been affected by global/regional environmental pressures. We compared the environmental characteristics and the BMI communities between 2000-2001 and 2017-2018. We identified three principal environmental changes (the air and water temperature increased, the lakes' water level declined, and the $\mathrm{pH}$ augmented and became more variable), and four principal ecological changes in the BMI communities [a species richness reduction (7 to 4), a composition change, and a dominant species replacement all of them in Lake El Sol, a species richness increase (2 to 4) in Lake La Luna, and a drastic reduction in density (38\% and $90 \%)$ and biomass $(92 \%)$ in both lakes]. The air and water temperature increased $0.5^{\circ} \mathrm{C}$, and lakes water level declined $1.5 \mathrm{~m}$, all suggesting an outcome of climate change. Contrarily to the expected acidification associated with acid precipitation, both lakes deacidified, and the annual $\mathrm{pH}$ fluctuation augmented. The causes of the deacidification and the deleterious impacts on the BMI communities remained to be identified.

Keywords: climate change; deacidification; benthos; crater lakes; Nevado de Toluca; Mexico

\section{Introduction}

Lake ecosystems are vulnerable to environmental change. This vulnerability makes them in good sentinels of environmental change [1]. The role of lakes as sentinels of climate change has been extensively recognized. Lakes provide early indications of climate change effects on ecosystem structure and functioning [2] and play as regulators of climate change [3].

Lakes comprise a geographically distributed network that makes them essential sentinels [4]; among them, high-mountain lakes are the most comparable ecosystems in the world [5]. Their naturally acidic waters with low alkaline reserve and mineralization make them especially sensitive to global change [6-8].

Climate change and airborne pollutants are critical environmental pressures on highmountain lakes leading, among other alterations, to the loss of diversity and changes in communities [9]. However, most studies on high-mountain lakes have been accomplished in temperate latitudes, while less information has come from tropical latitudes [10]. There 
are important differences between temperate and tropical lakes, mainly related to solar radiation [11]. As a consequence of higher and more constant irradiances, tropical high mountain lakes show higher minimum water temperatures, absence of winter ice cover, and predominance of warm polymixis thermal type, among other features [12].

Tropical lakes are more sensitive than temperate lakes to environmental alterations. For example, nutrient load increases led to prompter eutrophication, degrading water quality, and loss of deep-water dissolved oxygen concentration, all of these changes affecting the aquatic biota. The differences between temperate and tropical lakes limnology imply implementing different sound protection and management strategies [13].

Available information from tropical, high-mountain lakes is from the Andes [14], the Himalayas [12], Africa [15-17], and Central and South America [18-20]. Unfortunately, among them, the benthic macroinvertebrate (BMI) communities of tropical high-mountain lakes remained poorly known [5]; studies on BMI are scarcely available [21,22]. In this study, our primary goal was to understand how the environmental characteristics and the BMI communities of two tropical, high mountain lakes have been affected by global/regional environmental pressures. For this purpose, we addressed the following research questions: (1) How have the environmental water characteristics-particularly $\mathrm{pH}$ and water temperature-changed during the past 18 years? (2) How have the BMI community's composition and structure changed during the past 18 years?

Our central hypothesis was that regional anthropogenic activities (e.g., urban and industrial development) had affected the environmental and biological communities in the lakes. Specifically, we expected these anthropogenic activities to cause 1) warmer temperatures through global warming, (2) lake acidification associated with acid precipitation, and (3) BMI composition and structure modifications (e.g., species richness reduction).

To answer the research questions and test the proposed hypothesis, our approach was to evaluate the temporal changes in the (a) air temperature and rainfall using meteorological data derived from monthly monitoring within the past 18 years (2000 to 2018), (b) water quality of the lakes using data derived from monthly monitoring of the water column within the past 18 years (2000-2001 and 2017-2018), and (c) benthic macroinvertebrates' community composition and structure of the lakes using data derived from monthly monitoring of the benthic macroinvertebrate community within the past 18 years (2000-2001 and 2017-2018).

\section{Materials and Methods}

\subsection{Study Area}

Lakes El Sol and La Luna are inside the crater of the Nevado de Toluca volcano $\left(19^{\circ} 10^{\prime} \mathrm{N}, 99^{\circ} 45^{\prime} \mathrm{W}\right)$, Estado de México, Mexico, at $4240 \mathrm{~m}$ a.s.l. [23]. The lakes are separated by a dacitic dome known to cover the volcano's chimney (Figure 1). Nevado de Toluca is a Pleistocene age andesitic-dacitic stratovolcano [24,25]. The National Meteorological Service Weather Station SMN-15062 reports mean annual (1951-2010) temperature of $3.9^{\circ} \mathrm{C}\left(-0.6\right.$ to $\left.8.4^{\circ} \mathrm{C}\right)$, annual rainfall of $1277.1 \mathrm{~mm}$, and annual evaporation of $970.8 \mathrm{~mm}$, corresponding to a cold, alpine climate. Being above the timberline, the vegetation in the crater is sparse and consists of mosses, lichens, and alpine grasses.

Both lakes are endorheic with no affluents or effluents. Water inputs are rainfall and runoff, while the major water loss is through evaporation. The maximum depth recorded of Lake El Sol is $15 \mathrm{~m}$ (average depth $6 \mathrm{~m}$ ), with a surface area of $237,321 \mathrm{~m}^{2}$ (length $795 \mathrm{~m}$, width $482 \mathrm{~m}$ ), while the maximum depth of Lake La Luna is $10 \mathrm{~m}$ (depth mean of $5 \mathrm{~m}$ ), with a surface area of $31,083 \mathrm{~m}^{2}$ (length $227 \mathrm{~m}$, width $209 \mathrm{~m}$ ) [23]. Lake El Sol is discontinuous warm polymictic, while Lake La Luna is continuous warm polymictic [26]. 


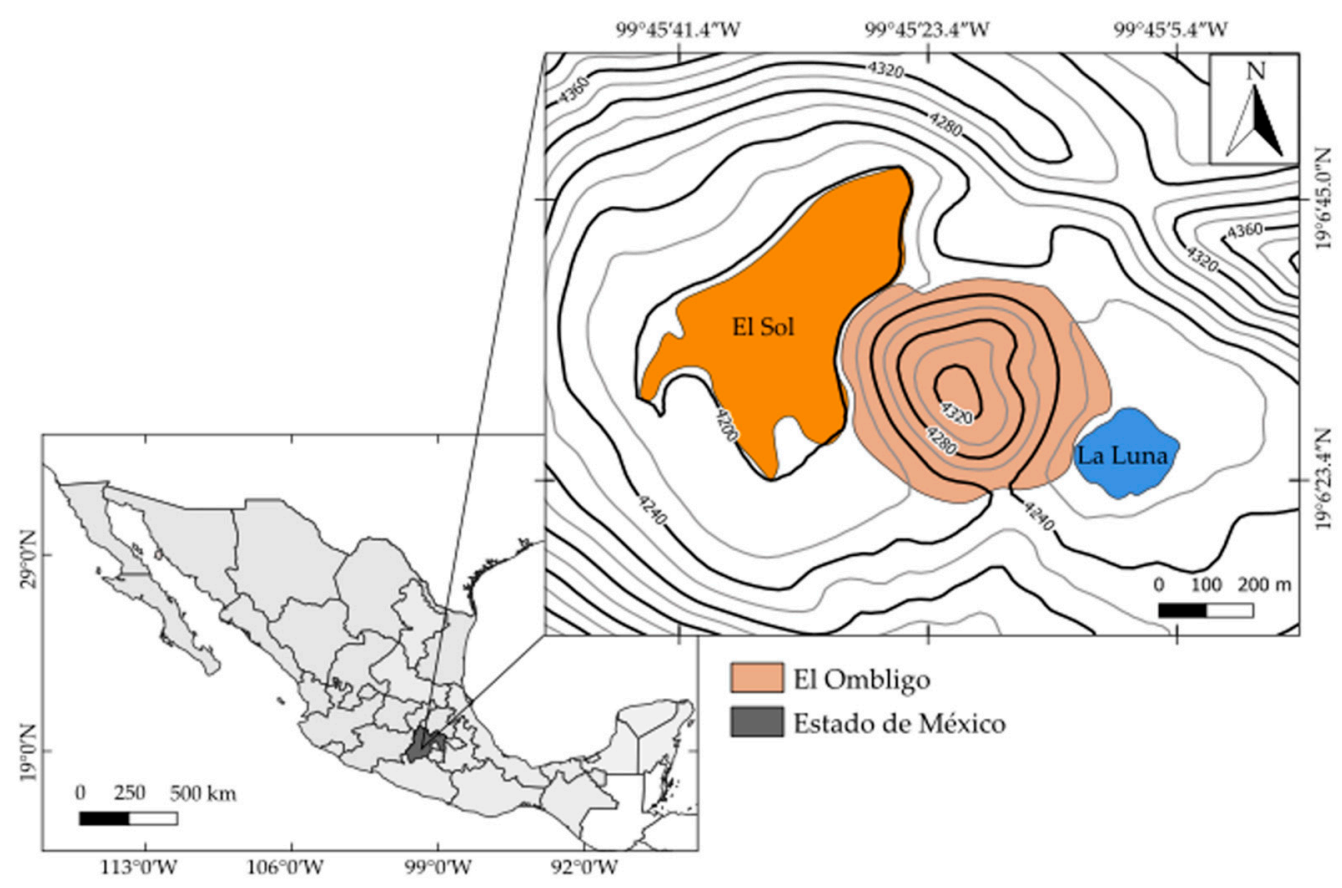

Figure 1. Location of Lakes El Sol and La Luna, Nevado de Toluca, Estado de México, Mexico. (Altitude in meters.)

\subsection{Field Sampling}

The environmental temperature and rainfall records between 2000 and 2018 were obtained from the Automatic Meteorological Station Nevado de Toluca (SMN-15062) at the Nevado de Toluca volcano $\left(19^{\circ} 07^{\prime} \mathrm{N}, 99^{\circ} 46^{\prime} \mathrm{W}, 4139 \mathrm{~m}\right.$ a.s.l.). We conducted two sampling campaigns for the monthly collection of water and surface sediment samples: March 2000 to March 2001 (12 sampling visits), and October 2017 to September 2018 (12 sampling visits). We first sampled Lake El Sol (12:00-14:00 h local time) and later sampled Lake La Luna (14:00-16:00 h).

Sampling took place in the central and deep part (>mean depth) of both lakes, which comprise around 50\% of the bottom area in Lake El Sol and 60\% in Lake La Luna. We measured water depth (echosounder) and water transparency (Secchi disk). In situ profiles (discrete readings every meter) of temperature, dissolved oxygen (DO), $\mathrm{pH}$, and electrical conductivity $\left(\mathrm{K}_{25}\right)$ were obtained with a calibrated multiparameter water-quality data logger (Hydrolab DS4 \& DS5).

Samples for sediment analysis and benthic macroinvertebrates were collected with an Ekman-type grab sampler $\left(0.0225 \mathrm{~m}^{2}\right.$ area, $\left.15 \times 15 \times 15 \mathrm{~cm}\right)$. We avoided sampling at the same site at each visit. A total of 4 replicates at each lake were collected per visit, one for sediment analysis and three for macroinvertebrates.

Three superficial subsamples were obtained from the first grab with a hand corer $\left(0.05 \mathrm{~cm}^{2}\right)$ for sediment texture and the other three for organic matter. Sediment texture was determined in a Beckman Coulter LS230 laser diffraction analyzer. Particle size was characterized following the classification scale of Wentworth [27]. The organic matter percentage $(\mathrm{OM})$ of the sediment was calculated based on the loss on ignition (LOI) technique [28].

The other three replicate samples (top $10 \mathrm{~cm}$ only) were sieved in situ through a $0.5 \mathrm{~mm}$ mesh pore size to retain the benthic macroinvertebrates [29]. The samples were preserved in 96\% alcohol [30]. The organisms were first identified according to general keys [31-34], followed by specific keys for oligochaetes [35-37], and chironomids [38-40]. The specimens of each species were quantified to determine their density (ind $\mathrm{m}^{-2}$ ). The specimens were further weighted (alcohol-fixed wet weight, FWW) [30], and their biomass calculated applying the conversion factors ( $\mathrm{mg}$ FWW to $\mathrm{mg} \mathrm{C}$ ) considering that $10 \%$ of the FWW is the ash-free dry weight (AFDW) and that $3.5 \%$ of the AFDW is organic carbon [41,42]. 


\subsection{Statistical Analysis}

The linear regressions of air temperature and rainfall versus time and the MannWhitney U tests comparing air temperature and rainfall between 2000-2001 and 2017-2018 periods were carried out with Sigma Plot. To compare the abundance and biomass of the BMI communities between lakes in 2000-2001, a paired samples Student's $t$-test was used, and the data was $\ln$-transformed $[\ln (x+1)]$ to reduce skewed distributions. We first verified that normality (Kolmogorov-Smirnov test) and homogeneity (Levene test) of variance assumptions were met for all Student's $t$-test. A Mann-Whitney U test (which corresponds to a non-parametric analysis of the Student's $t$-test) was performed to compare the lakes in 2017-2018 and between periods.

\section{Results}

\subsection{The Environment}

There was an increasing trend in air temperature with a total change of $0.5{ }^{\circ} \mathrm{C}$ $\left(0.03{ }^{\circ} \mathrm{C}^{-1}\right)$ in 18 years $(\mathrm{r}=0.12)$. Differently, rainfall did not show a regular trend $(\mathrm{r}=0.03)$ nor significant difference (Mann-Whitney $\mathrm{U}$ Statistic, $\mathrm{T}=528, n$ small $=22, n$ big $=24$, $p=0.817$ ) along the same period (Figure 2). The average air temperature was significantly higher in 2017-2018 than 2000-2001 (Mann-Whitney U Statistic, T $=418, n$ small $=22$, $n$ big $=24, p=0.030$ ), differently from rainfall which remained similar.
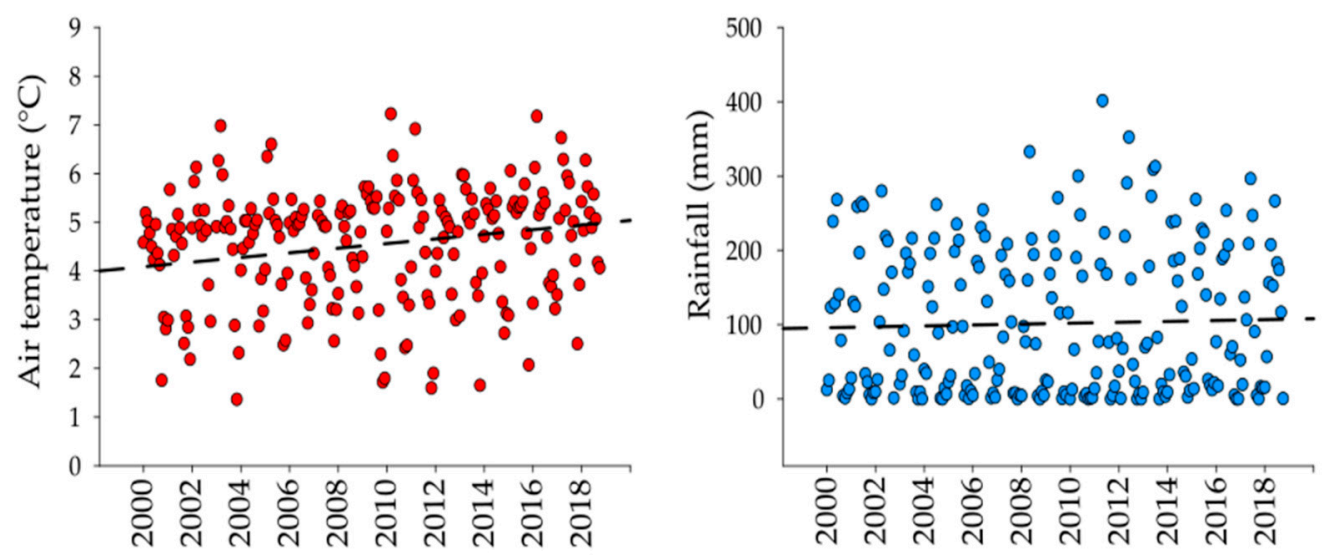

Figure 2. Air temperature (red dots) and rainfall (blue dots) trends from 2000 to 2018. Dots represent monthly average values of air temperature and rainfall. (Automatic Meteorological Station Nevado de Toluca SMN-15062).

Table 1 reports the main environmental characteristics measured in Lakes El Sol and La Luna in 2000-2001 and 2017-2018. Water depth diminished in both lakes (approximately $1.5 \mathrm{~m})$. Moreover, the water temperature also increased in both lakes $\left(0.5^{\circ} \mathrm{C}\right)$, while $\mathrm{K}_{25}$ increased and DO concentration diminished in Lake El Sol. All these changes suggest higher evaporation rates associated with higher environmental and water temperatures. However, and contradicting, $\mathrm{K}_{25}$ in Lake La Luna remained similar while DO concentration increased.

Contrarily to the expected acidification process associated with anthropogenic activities and airborne pollution, $\mathrm{pH}$ increased in both lakes, particularly in El Sol which changed $0.85 \mathrm{pH}$ units between 2000-2001 to 2017-2018. La Luna's pH increased was minor with $0.11 \mathrm{pH}$ units. Additionally, the annual $\mathrm{pH}$ range (min-max) increased between both periods in both lakes. Lake El Sol's pH annual range rose from 1.21 to $4.56 \mathrm{pH}$ units, while Lake La Luna changed from 0.91 to $2.61 \mathrm{pH}$ units between 2000-2001 to 2017-2018. In 18 years, $\mathrm{pH}$ augmented and became more variable on an annual basis (Figure 3 ). 
Table 1. Environmental variables (average \pm standard deviation) of Lakes El Sol and La Luna, Nevado de Toluca, measured in 2000-2001 and 2017-2018 annual cycles. (Z $\mathrm{Z}_{\mathrm{SD}}=$ Secchi disk depth, ${ }^{\mathrm{a}}=$ total water transparency, $\mathrm{DO}=$ dissolved oxygen, $\mathrm{K}_{25}=$ electrical conductivity, $\mathrm{OM}=$ sedimentary organic matter, Texture = average grain size $).\left({ }^{b}=\right.$ calculated by first transforming $\mathrm{pH}$ to $\mathrm{H}^{+}$concentrations).

\begin{tabular}{|c|c|c|c|c|c|}
\hline \multirow{2}{*}{ Variable } & \multirow{2}{*}{ Unit } & \multicolumn{2}{|c|}{ El Sol } & \multicolumn{2}{|c|}{ La Luna } \\
\hline & & $2000-2001$ & 2017-2018 & $2000-2001$ & 2017-2018 \\
\hline Air temperature & ${ }^{\circ} \mathrm{C}$ & $4.2 \pm 1.0$ & $5.0 \pm 1.1$ & $4.2 \pm 1.0$ & $5.0 \pm 1.1$ \\
\hline Annual rainfall & $\mathrm{mm}$ & 2367 & 2521 & 2367 & 2521 \\
\hline Monthly rainfall & $\mathrm{mm}$ & $107.6 \pm 100.3$ & $109.3 \pm 97.7$ & $107.6 \pm 100.3$ & $109.3 \pm 97.7$ \\
\hline $\mathrm{Z}_{\mathrm{MAX}}$ & $\mathrm{m}$ & 13.5 & 12.0 & 11.0 & 9.5 \\
\hline $\mathrm{Z}_{\mathrm{SD}}$ & $\mathrm{m}$ & $4.6 \pm 1.0$ & $4.1 \pm 0.3$ & $10.2 \pm 0.4^{\mathrm{a}}$ & $8.8 \pm 0.4^{\mathrm{a}}$ \\
\hline $\begin{array}{c}\text { Water } \\
\text { temperature }\end{array}$ & ${ }^{\circ} \mathrm{C}$ & $8.58 \pm 1.96$ & $9.3 \pm 1.60$ & $8.43 \pm 1.73$ & $9.10 \pm 2.10$ \\
\hline Average $\mathrm{pH}^{\mathrm{b}}$ & & 5.28 & 6.13 & 4.65 & 4.76 \\
\hline $\mathrm{pH}$ range & & $4.92-6.13$ & $5.07-9.63$ & $4.51-5.42$ & $4.01-6.62$ \\
\hline $\mathrm{DO}$ & $\mathrm{mg} \mathrm{L}^{-1}$ & $6.7 \pm 0.8$ & $6.0 \pm 2.0$ & $6.7 \pm 0.8$ & $6.9 \pm 0.3$ \\
\hline $\mathrm{K}_{25}$ & $\mu \mathrm{S} \mathrm{cm}^{-1}$ & $16 \pm 1$ & $63 \pm 20$ & $14 \pm 1$ & $12 \pm 3$ \\
\hline $\mathrm{OM}$ & $\%$ & $12 \pm 3$ & $14 \pm 3$ & $18 \pm 4$ & $16 \pm 3$ \\
\hline Texture & $\mathrm{mm}$ & $0.002-0.05$ & $0.002-0.05$ & $0.002-0.05$ & $0.002-0.05$ \\
\hline Substrate type & & fine silt & fine silt & fine silt & fine silt \\
\hline
\end{tabular}

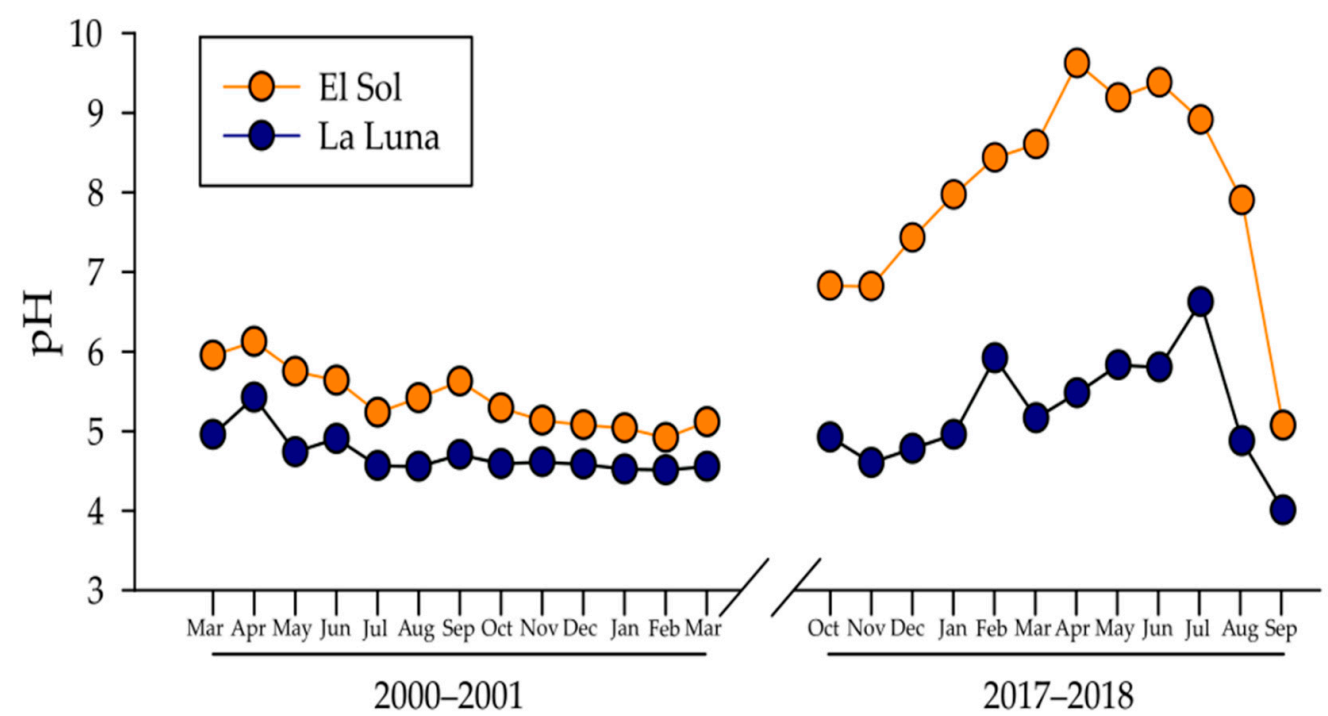

Figure 3. Temporal dynamics of $\mathrm{pH}$ in Lakes El Sol (orange dots) and La Luna (blue dots).

The lowest pH values in Lake El Sol changed from 4.92 in 2000-2001 to 5.07 in 2017-2018, while in Lake La Luna from 4.51 in 2000-2001 to 4.01 in 2017-2018. The highest $\mathrm{pH}$ values in Lake El Sol changed from 6.13 in 2000-2001 to 9.63 in 2017-2018, while in Lake La Luna from 5.42 in 2000-2001 to 6.62 in 2017-2018 (Table 1). It must be noticed that while Lake La Luna's pH ranges from acid to close to neutrality, Lake El Sol's pH rose from acidic to strongly alkaline $\mathrm{pH}$.

Sediment texture and organic matter in Lakes El Sol and La Luna were similar. Also, sediment texture and organic matter content remained similar in 2000-2001 and 2017-2018 (Table 1).

\subsection{The Benthic Macroinvertebrate Community}

The taxonomic list reported for both lakes of the Nevado de Toluca (2000-2001 and 2017-2018) sum a total of 8 species: 7 for 2000-2001 and 6 for 2017-2018 (Table 2). Four 
species belong to the phylum Annelida, two species to Mollusca, one to Arthropoda, and one to Cnidaria.

Table 2. Taxonomic list of the benthic macroinvertebrates of Lakes El Sol and La Luna, Nevado de Toluca. $(\mathrm{X}=$ presence, $-=$ absence).

\begin{tabular}{|c|c|c|c|c|c|}
\hline \multirow{2}{*}{ Family } & \multirow{2}{*}{ Species } & \multicolumn{2}{|c|}{ El Sol } & \multicolumn{2}{|c|}{ La Luna } \\
\hline & & $2000-2001$ & 2017-2018 & 2000-2001 & 2017-2018 \\
\hline \multirow[t]{3}{*}{ Naididae } & $\begin{array}{c}\text { Nais pardalis Piguet, } \\
1906\end{array}$ & $x$ & $X$ & - & $x$ \\
\hline & $\begin{array}{l}\text { Limnodrilus } \\
\text { hoffmeisteri } \\
\text { Claparède, } 1862\end{array}$ & $X$ & $X$ & $X$ & $x$ \\
\hline & $\begin{array}{l}\text { Tubifex tubifex Muller, } \\
1774\end{array}$ & $X$ & - & - & - \\
\hline Lumbriculidae & $\begin{array}{c}\text { Lumbriculus } \\
\text { variegatus Müller, } \\
1774\end{array}$ & $X$ & - & - & $x$ \\
\hline Chironomidae & $\begin{array}{c}\text { Pseudodiamesa } \\
\text { branickii } \\
\text { Makarchenko \& } \\
\text { Makarchenko, } 1999\end{array}$ & $X$ & - & $X$ & $x$ \\
\hline Hydridae & $\begin{array}{c}\text { Hydra vulgaris Pallas, } \\
1766\end{array}$ & $X$ & $x$ & - & - \\
\hline Physidae & $\begin{array}{c}\text { Physa sp. } \\
\text { Draparnaud, } 1801\end{array}$ & - & $X$ & - & - \\
\hline Spaeriidae & $\begin{array}{c}\text { Pisidium casertanum } \\
\text { Poli, } 1791\end{array}$ & $x$ & - & - & - \\
\hline
\end{tabular}

Table 3 reports the main ecological characteristics evaluated in Lakes El Sol and La Luna in 2000-2001 and 2017-2018. From 2000-2001 to 2017-2018, there was a species richness reduction in Lake El Sol from 7 to 4 species, while Lake La Luna increased from 2 to 4 species. In Lake El Sol, N. pardalis, L. hoffmeisteri and H. vulgaris remained, T. tubifex, L. variegatus, P. branickii and P. casertanum disappeared, while Physa sp. appeared. In Lake La Luna, L. hoffmeisteri and P. branickii remained, while N. pardalis and Lumbriculus variegatus appeared. The average species richness in Lake El Sol was $5 \pm 1$ in 2000-2001, while $2 \pm 1$ species in 2017-2018. In Lake La Luna, average species richness was $2 \pm 0$ in 2000-2001, while $2 \pm 1$ species in 2017-2018.

Table 3. Ecological variables (average \pm standard deviation) of Lakes El Sol and La Luna, Nevado de Toluca, measured in 2000-2001 and 2017-2018 annual cycles. ( $\mathrm{S}=$ species richness, Avg = average).

\begin{tabular}{cccccc}
\hline \multirow{2}{*}{ Variable } & \multirow{2}{*}{ Unit } & \multicolumn{2}{c}{ El Sol } & \multicolumn{2}{c}{ La Luna } \\
\cline { 3 - 6 } & & $\mathbf{2 0 0 0 - 2 0 0 1}$ & $\mathbf{2 0 1 7 - 2 0 1 8}$ & $\mathbf{2 0 0 0 - 2 0 0 1}$ & $\mathbf{2 0 1 7 - 2 0 1 8}$ \\
\hline S & species & 7 & 4 & 2 & 4 \\
Avg S & species & $5 \pm 1$ & $2 \pm 1$ & $2 \pm 0$ & $2 \pm 1$ \\
Avg Density & ind m $^{-2}$ & $6541 \pm 7414$ & $2453 \pm 2949$ & $7955 \pm 7349$ & $783 \pm 1042$ \\
Avg Biomass & mg C m $^{-2}$ & $47.49 \pm 54.28$ & $3.63 \pm 4.43$ & $50.44 \pm 54.33$ & $3.69 \pm 7.35$ \\
\hline
\end{tabular}

BMI average annual density in 2000-2001 in Lake El Sol $\left(6541 \pm 7414\right.$ ind $\left.\mathrm{m}^{-2}\right)$ was $82 \%$ of Lake La Luna $\left(7955 \pm 7349\right.$ ind $\left.\mathrm{m}^{-2}\right)$. Nonetheless, there were no significant differences in the BMI density of both lakes (Student's $t$-tests, $n=24, \mathrm{t}=3.78, p=0.59$ ). The BMI average annual density in 2017-2018 in Lake El Sol $\left(2453 \pm 2949\right.$ ind $\left.\mathrm{m}^{-2}\right)$ was much higher $(68 \%)$ than in Lake La Luna $\left(783 \pm 1042\right.$ ind $\left.\mathrm{m}^{-2}\right)$. In this case, there were significant differences in the BMI density values of both lakes (Student's $t$-tests, $n=24$, $\mathrm{t}=2.51, p=0.17$ ). Quite differently, BMI average annual density in 2017-2018 in both lakes 
was much lower than in 2000-2001 with a percent decrease of 63\% in Lake El Sol and 90\% in Lake La Luna (Table 4, Figure 4).

Table 4. Recurrence percentage (Rec.), and BMI density and biomass (average \pm standard deviation and \% of annual density and biomass) of Lakes El Sol and La Luna, Nevado de Toluca, measured in 2000-2001 and in 2017-2018.

\begin{tabular}{|c|c|c|c|c|c|c|c|c|c|c|}
\hline \multirow[b]{3}{*}{ El Sol } & \multicolumn{5}{|c|}{ 2000-2001 } & \multicolumn{5}{|c|}{ 2017-2018 } \\
\hline & \multirow{2}{*}{$\begin{array}{c}\text { Rec. } \\
\%\end{array}$} & \multicolumn{2}{|c|}{ Density } & \multicolumn{2}{|c|}{ Biomass } & \multirow{2}{*}{$\begin{array}{c}\text { Rec. } \\
\%\end{array}$} & \multicolumn{2}{|c|}{ Density } & \multicolumn{2}{|c|}{ Biomass } \\
\hline & & ind $m^{-2}$ & $\%$ & $\mathrm{mg} \mathrm{C} \mathrm{m}^{-2}$ & $\%$ & & ind $\mathrm{m}^{-2}$ & $\%$ & $\mathrm{mg} \mathrm{C} \mathrm{m}^{-2}$ & $\%$ \\
\hline N. pardalis & 41.7 & $19 \pm 47$ & 0.3 & $\begin{array}{c}0.03729 \pm \\
0.10008\end{array}$ & 0.1 & 75.0 & $\begin{array}{c}1018 \pm \\
1999\end{array}$ & 41.5 & $\begin{array}{c}0.00144 \pm \\
0.00290\end{array}$ & 39.7 \\
\hline $\begin{array}{c}\text { L. } \\
\text { hoffmeisteri }\end{array}$ & 66.7 & $51 \pm 106$ & 0.8 & $\begin{array}{c}0.23986 \pm \\
046451\end{array}$ & 0.5 & 83.3 & $\begin{array}{c}1385 \pm \\
2101\end{array}$ & 56.5 & $\begin{array}{c}0.00213 \pm \\
0.00345\end{array}$ & 58.8 \\
\hline T. tubifex & 100 & $4807 \pm 6557$ & 73.5 & $\begin{array}{c}25.22899 \pm \\
42.68366\end{array}$ & 53.1 & - & - & - & - & - \\
\hline $\begin{array}{c}L . \\
\text { variegatus }\end{array}$ & 91.7 & $1068 \pm 1426$ & 16.3 & $\begin{array}{c}13.22973 \pm \\
18.86350\end{array}$ & 27.9 & - & - & - & - & - \\
\hline P. branickii & 8.3 & $1 \pm 7$ & 0.0 & $\begin{array}{c}0.00561 \pm \\
0.03367\end{array}$ & 0.0 & - & - & - & - & - \\
\hline H. vulgaris & 58.3 & $25 \pm 74$ & 0.4 & $\begin{array}{c}0.00798 \pm \\
0.01785\end{array}$ & 0.0 & 16.7 & $16 \pm 56$ & 0.6 & $\begin{array}{c}0.00002 \pm \\
0.00007\end{array}$ & 0.5 \\
\hline Physa sp. & - & - & - & - & - & 16.7 & $33 \pm 147$ & 1.4 & $\begin{array}{c}0.00004 \pm \\
0.00017\end{array}$ & 1.0 \\
\hline $\begin{array}{c}P . \\
\text { casertanum }\end{array}$ & 100 & $571 \pm 754$ & 8.7 & $\begin{array}{c}8.73803 \pm \\
11.44316\end{array}$ & 18.4 & - & - & - & - & - \\
\hline \multicolumn{11}{|l|}{ La Luna } \\
\hline N. pardalis & - & - & - & - & - & 33.3 & $40 \pm 115$ & 5.0 & $\begin{array}{c}0.00031 \pm \\
0.00145\end{array}$ & 8.3 \\
\hline $\begin{array}{c}\text { L. } \\
\text { hoffmeisteri }\end{array}$ & 100 & $7808 \pm 7270$ & 98.2 & $\begin{array}{c}47.79901 \pm \\
53.47725\end{array}$ & 94.8 & 91.7 & $\begin{array}{c}734 \pm \\
1038\end{array}$ & 93.3 & $\begin{array}{c}0.00309 \pm \\
0.00661\end{array}$ & 83.7 \\
\hline P. branickii & 100 & $146 \pm 162$ & 1.8 & $\begin{array}{c}2.64082 \pm \\
3.23424\end{array}$ & 5.2 & 25.0 & $10 \pm 26$ & 1.3 & $\begin{array}{c}0.00018 \pm \\
0.00051\end{array}$ & 4.8 \\
\hline $\begin{array}{c}L . \\
\text { variegatus }\end{array}$ & - & - & - & - & - & 8.3 & $4 \pm 22$ & 0.4 & $\begin{array}{c}0.00012 \pm \\
0.00070\end{array}$ & 3.2 \\
\hline
\end{tabular}

The maximum density of the BMI in Lake El Sol in 2000-2001 was $13,809 \pm 15,517$ ind $\mathrm{m}^{-2}$, and the minimum was $921 \pm 287$ ind $\mathrm{m}^{-2}$ in November and December, respectively. Throughout 2017-2018, the maximum density was $5214 \pm 3713$ ind $\mathrm{m}^{-2}$ in February, and in June, there were no organisms (Figure 4).

The BMI maximum density in Lake La Luna during 2000-2001 was $15,102 \pm 13,789$ ind $\mathrm{m}^{-2}$, found in May, while the minimum $\left(803 \pm 1013\right.$ ind $\left.\mathrm{m}^{-2}\right)$ occurred in January. During 2017-2018, the maximum density was recorded in February (3066 \pm 395 ind m$^{-2}$ ) and the minimum (absence of organisms) in May (Figure 4). There was no temporal pattern in the BMI density in both lakes and both periods. 


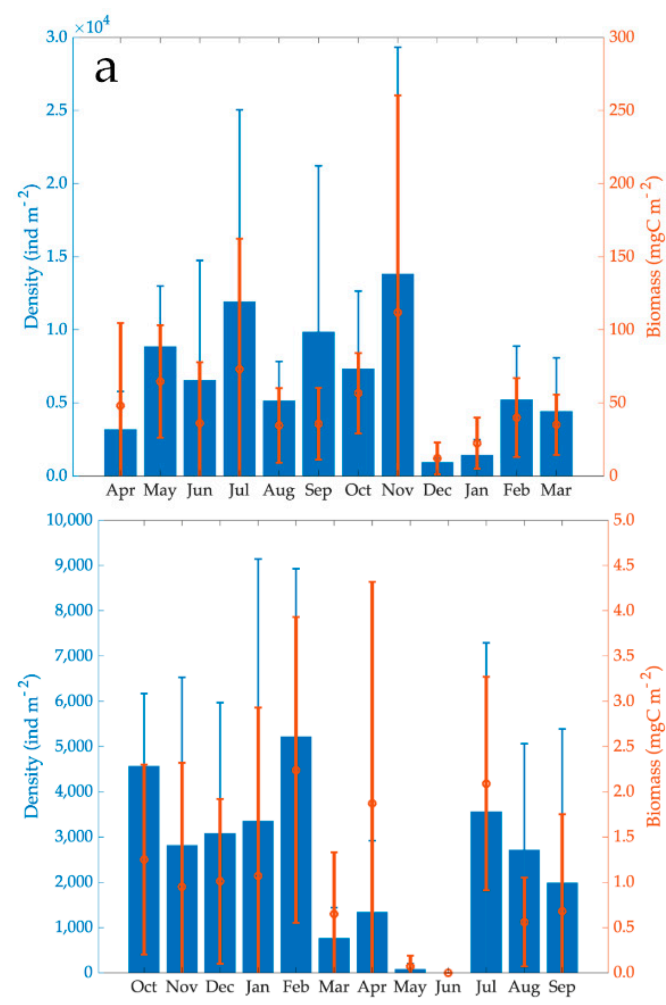

C

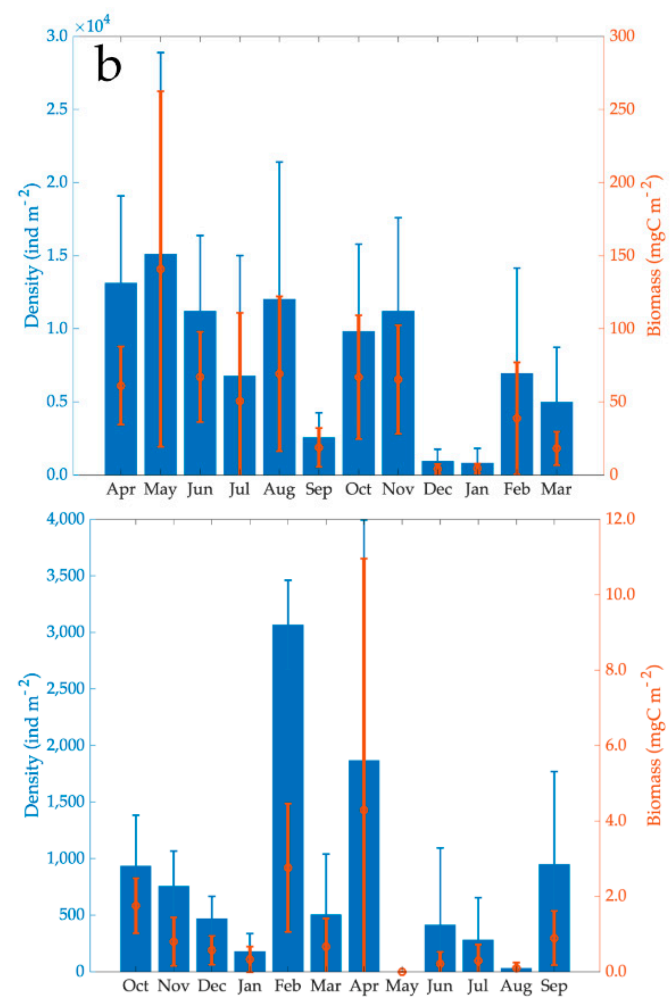

d

Figure 4. Temporal dynamics of the BMI density and biomass (average \pm standard deviation) in Lake El Sol ((a): 2000-2001, (c): 2017-2018), and Lake La Luna ((b): 2000-2001, (d): and 2017-2018).

In both annual cycles, the annelids numerically dominated the BMI community in both lakes. In 2000-2001, T. tubifex (73.5\%) and L. variegatus (16.3\%) composed most of the BMI community (89.8\%) in Lake El Sol. In Lake La Luna, L. hoffmeisteri was dominant with $98.2 \%$ of the BMI community. In 2017-2018, annelids remained the dominant benthic component in Lake El Sol, but in 2000-2001 the species were replaced by L. hoffmeisteri $(56.5 \%)$ and $N$. pardalis $(41.5 \%)$, which composed most of the BMI community $(98 \%)$. Differently, L. hoffmeisteri (93.3\%) remained to be dominant in Lake La Luna.

BMI average annual biomass in 2000-2001 in Lake El Sol (47.49 $\left.\pm 54.28 \mathrm{mg} \mathrm{C} \mathrm{m}^{-2}\right)$ was around $94 \%$ of that in Lake La Luna ( $50.44 \pm 54.33 \mathrm{mg} \mathrm{C} \mathrm{m}^{-2}$ ). The 2017-2018 BMI average annual biomass in Lake El Sol $\left(3.63 \pm 4.43 \mathrm{mg} \mathrm{C} \mathrm{m}^{-2}\right)$ was around $98 \%$ of that in Lake La Luna (3.69 $\pm 7.35 \mathrm{mg} \mathrm{C} \mathrm{m}^{-2}$ ). There were no significant differences in the BMI average biomasses of both lakes (Mann-Whitney U Statistic, $\mathrm{T}=79, n=24, p=0.617$ ) in both periods (Mann-Whitney U Statistic, $\mathrm{T}=64, n=24, p=0.652$ ). The BMI average annual biomass in 2017-2018 in both lakes was much lower than in 2000-2001, a reduction of 92\% in El Sol and 93\% in La Luna (Table 4, Figure 4).

The maximum BMI biomass in Lake El Sol in 2000-200 was $111.86 \pm 148.37 \mathrm{mg} C$ $\mathrm{m}^{-2}$ in November, while the minimum with $12.08 \pm 10.90 \mathrm{mg} \mathrm{C} \mathrm{m}^{-2}$ in December. In 2017-2018, the maximum biomass was found in February with $2.24 \mathrm{mg} \mathrm{C} \mathrm{m}^{-2}$ and the minimum in June with no organisms. In Lake La Luna in 2000-2001, the maximum BMI biomass was found in May $\left(140.86 \pm 121.61 \mathrm{mg} \mathrm{C} \mathrm{m}^{-2}\right)$ and the minimum in December $\left(12.08 \pm 10.90 \mathrm{mg} \mathrm{C} \mathrm{m}^{-2}\right)$. For 2017-2018, the maximum was $4.29 \pm 6.67 \mathrm{mg} \mathrm{C} \mathrm{m}^{-2}$ in February and the minimum with no organisms in June. There were no temporal biomass dynamics in both lakes and in both periods.

In both annual cycles, the annelids dominated the biomass of the BMI community in both lakes. In 2000-2001, T. tubifex (53.1\%) and L. variegatus (27.9\%) composed most of the BMI community $(81.0 \%)$ in Lake El Sol. In Lake La Luna, L. hoffmeisteri was dominant with $94.8 \%$ of the BMI community. In 2017-2018, annelids remained dominant in Lake El Sol, 
but the 2000-2001 species were replaced by L. hoffmeisteri (59.2\%) and N. pardalis (40.0\%), which composed most of the BMI community (99.3\%). Unlike Lake El Sol, similarly to 2000-2001, L. hoffmeisteri (83.6\%) remained dominant in Lake La Luna.

\section{Discussion}

\subsection{The Environment}

We anticipated an increase in air temperature and decrease rainfall, both evidencing a response to climate change. We recorded a $0.5^{\circ} \mathrm{C}$ increase in air temperature at the Nevado de Toluca between 2000-2001 and 2017-2018 (18 years) in good agreement with the Intergovernmental Panel on Climate Change [43] report about a temperature increase of $0.5^{\circ} \mathrm{C}$ in 50 years as indicative of climate change. Air temperature warming in high altitude mountains occurs at an average rate of $0.3^{\circ} \mathrm{C}$ per decade with a $\pm 0.2{ }^{\circ} \mathrm{C}$ variability [44]. In general, warming is enhanced above $500 \mathrm{~m}$ a.s.l., the elevation-dependent warming data are insufficient and contradictory. Some studies have demonstrated that anthropogenic greenhouse emissions are one of the dominant factors of temperature increase above $4000 \mathrm{~m}$ a.s.l. [44]. In the tropics, warming can be enhanced at higher elevation by a reduction of the vertical temperature gradient due to increased latent heat released above the condensation level, favored in a warmer and moister atmosphere [45].

Air and water temperatures but not rainfall suggested evidence of the expected climate change; air and lakes' water temperatures increased $0.5^{\circ} \mathrm{C}$, and water levels diminished around $1.5 \mathrm{~m}$. Lake levels evidence changes in water quantity availability by reflecting the balance between water input (rainfall, runoff) and loss (evaporation), and it is often related to long-term cyclic climatic changes [2,46]. The warming rate in other high altitude lakes in the Tibetan Plateau has been $0.055 \pm 0.022{ }^{\circ} \mathrm{C} \mathrm{yr}^{-1}$. The $\mathrm{K}_{25}$ increase in Lake El Sol suggested a higher evaporation rate since increase weathering carrying solutes to the lake would require more significant rainfall rates, which was not the case. The relatively low mineralization of Lake La Luna and the smaller lake's water volume and micro-drainage basin could probably explain the lack of detectable response in $\mathrm{K}_{25}$.

Numerous high mountain lakes worldwide have been acidified associated with the widespread problem of acid precipitation [47]; $\mathrm{pH}$ decreases are between 0.5 and $1 \mathrm{pH}$ units [48]. Examples of acidification of high mountain lakes are found ubiquitously, for example, in European lakes [49] and the Adirondack Mountains in New York [50].

Also, some documented cases of $\mathrm{pH}$ increase (recovery) in high mountain lakes in Europe and North America [49,51-54]. The $\mathrm{pH}$ increases-deacidification-in these cases resulted from the diminution of the emission and deposit of sulfur and nitrogen oxides due to international agreements to reduce atmospheric pollutant emissions. The $\mathrm{pH}$ in these "recovered" lakes changed from anthropogenic (acid precipitation) acidity $(\mathrm{pH}<5)$ to "natural" water acidity [55]. Lakes El Sol and la Luna display a similar deacidification process. However, it seems the answer to this recovery is not reducing the acid species into the atmosphere. Bulk deposition $\mathrm{pH}$ at the Nevado de Toluca volcano remained acidic all year round [56], so acidification instead of deacidification of both lakes was expected.

The $\mathrm{pH}$ increased in both lakes, and the $\mathrm{pH}$ annual fluctuation range also increased, particularly in Lake El Sol. The broad $\mathrm{pH}$ changes in both periods are most likely explained by the lakes' low buffer capacity (i.e., alkaline reserve). However, the wider $\mathrm{pH}$ range in Lake El Sol was unexpected considering alkalinity is lower in Lake La Luna (2003: $2.1 \pm 0.3 \mathrm{mg} \mathrm{L}^{-1}, 2017-2018: 1.1 \pm 0.9 \mathrm{mg} \mathrm{L}^{-1}$ ) than in Lake El Sol (2003: $27.5 \pm 0 \mathrm{mg} \mathrm{L}^{-1}$, 2017-2018: $21.6 \pm 3.1 \mathrm{mg} \mathrm{L}^{-1}$ ) (2003 data, [48]; 2017-2018, unpublished data). In addition, it must be noted that alkalinity declined $\sim 48 \%$ in Lake El Sol and $21 \%$ in Lake La Luna from 2003 to 2017-2018, which also explains the increase in the $\mathrm{pH}$ variation ranges in 2017-2018.

\subsection{The Benthic Macroinvertebrate Community}

The species diversity in high mountain lakes is usually low [21,57]; nonetheless, the species richness found in Lakes El Sol and La Luna was particularly low (8 species), 
compared with other high-mountain lakes of up to 180 species found in six lakes [22,57-59]. Altitude seems to influence the BMI communities' composition, abundance, and diversity, which decline with higher altitudes, probably responding to harsher environments at higher altitudes [60]. Habitats become less complex [44]. Lakes El Sol and La Luna are above $4000 \mathrm{~m}$ a.s.l., representing harsher environments.

The overall dominance of annelids over chironomids in Lakes El Sol and La Luna in both cycles contrasts with the findings in Alpine lakes [60], where chironomid dominated BMI, particularly with increasing acidity, with larger dominance as altitude augmented most likely associated to their dispersal mechanisms. Also, other studies reported chironomid as the principal BMI component in the High-Andean lakes and temporary and permanent Tatra Mountains' lakes [22,58]. These studies also found the presence of annelids, but their contribution was well below that of chironomids.

The dominance of chironomids over annelids is explained mainly because oligochaetes exhibit a slow dispersal process and need a transportation vector or a passive dispersion mechanism through the air as cysts and cocoons. Although a negative correlation with altitude in high mountain lakes, its frequency of appearance is usually high $(>70 \%)$ [61]. However, chironomids' higher dispersal abilities explain their high frequency of appearance and higher abundance in high mountain lakes than annelids. Chironomids dominate in strongly acidified and alpine acidified lakes, while annelids in subalpine acidified and non-acidified lakes [62]. The latter suggests higher $\mathrm{pHs}$ and lower altitudes favor annelids, while lower $\mathrm{pHs}$ and higher altitudes favor chironomids (e.g., [63]).

Lakes El Sol and La Luna were already acidified (i.e., $\mathrm{pH}<5.6$ ) in 2000-2001, this is, the low $\mathrm{pH}$ and the high altitude of both lakes should have favored chironomids and not annelids as found. Refs. $[64,65]$ found organisms buried inside the sediments (infauna) like annelids display a delayed reaction to acidification in comparison with those living above (epifauna) the sediments. Besides, acidification affects BMI physiologically through acid anions $\left(\mathrm{H}^{+}\right)$but also altering other chemicals (e.g., aluminum concentration) and biological (e.g., food availability, biotic interactions) characteristics (e.g., [66]). Ref. [44] reported that species composition and abundance have markedly changed in high mountain ecosystems in recent decades. Some cold-adapted species, including endemics, have declined in abundance in freshwater communities and will continue to decline in the following decades. A combination of factors not yet identified could answer the annelid dominance over chironomids in Lakes El Sol and La Luna.

The dominant species positively correlated with $\mathrm{pH}$ and temperature in both lakes in 2000-2001. Similar positive correlations between the dominant species and $\mathrm{pH}$ and temperature in both lakes were found in 2017-2018. The positive correlations between the dominant species and temperature and $\mathrm{pH}$ indicate higher temperatures and $\mathrm{pHs}$ promote larger BMI densities and biomasses. However, this is not the case when both periods are included in the same correlation analysis. The higher water temperature and $\mathrm{pH}$ in both lakes in 2017-2018 compared to 2000-2001 did not mirror in higher but instead much lower densities (Lake El Sol: 63\% and Lake La Luna: 90\% reduction) and biomasses (>90\% reduction) in 2017-2018 compared to 2000-2001. The latter indicates the comparatively significant change in temperature and $\mathrm{pH}$ from 2000-2001 to 2017-2018 harmed the BMI leading to a drastic reduction in their densities and biomasses in both lakes.

While the 2000-2001 and 2017-2018 increase in temperature is similar in both lakes, the $\mathrm{pH}$ change in Lake El Sol is much more significant than in Lake La Luna. The latter could be the main reason explaining the more extensive changes in the BMI community of Lake El Sol (lower species richness, dominant species replacement, lower density, and biomass) comparing with the comparatively "minor" changes in Lake La Luna (species richness increase, lower density, and biomass). The higher $\mathrm{pH}$ and the larger annual fluctuation in Lake El Sol in 2017-2018, ranging from acidic (5.07) to strongly alkaline (9.63), probably led to the more significant changes in the BMI. Lake La Luna $\mathrm{pH}$ also fluctuated in 2017-2018 but remained within the acid range (4.01 to 6.62). 
Most investigations look for identifying the effects of acidification on high mountain lakes. Many of them found that anthropogenic acidification does not affect the zoobenthos [58,65,67-69]. In contrast, others indicate the macrobenthic invertebrate community will be significantly simplified, with only resistant species able to cope with the acid conditions [64]. However, both Lakes El Sol and La Luna illustrate an opposite case; instead of an acidification process, the lakes underwent deacidification. The two lakes were already acidified in 2000-2001, while in 2017-2018, both lakes were deacidified. It seems deacidification did not foster the BMI communities' recovery, as suggested by the drastic reduction in the density and biomass of the BMI communities of both lakes.

\section{Conclusions}

The anthropogenic activities (acid precipitation, climate change) lead to environmental changes and then on the composition and structure of the BMI communities of Lakes El Sol and La Luna from 2000-2001 to 2017-2018. Air and water temperature increased $0.5^{\circ} \mathrm{C}$, while water level declined $1.5 \mathrm{~m}$ in both lakes. Contrarily to the lakes' expected acidification associated with acid precipitation, we found deacidification in both lakes. The BMI density and biomass were drastically reduced in both lakes. More extensive changes in Lake El Sol (species richness reduction, change in species composition, and dominant species replacement) respecting Lake La Luna are most likely associated with the more significant increase in $\mathrm{pH}$ in the former and probably the wider $\mathrm{pH}$ annual fluctuation from acid to strongly alkaline in Lake El Sol. The causes of the deacidification and the deleterious impacts on the BMI communities remained to be uncovered. Identified changes in Lake El Sol and Lake La Luna showed unexpected responses to global change (e.g., deacidification), illustrating the relevance of better known and understand the limnology of tropical high mountain lakes to provide the scientific basis to implement protection and management actions to avoid further environmental deterioration, and even restoration actions.

Author Contributions: Conceptualization, J.A., L.A.O., E.E.; methodology, J.A., L.A.O., D.I.-M.; software, L.A.O., D.I.-M., L.G.-C.; validation, J.A., L.A.O., D.I.-M., E.E.; formal analysis, J.A., L.A.O., D.I.-M., E.E., L.G.-C.; investigation, J.A., L.A.O., D.I.-M., E.E., L.G.-C.; resources, J.A.; data curation, D.I.M., L.G.-C.; writing—original draft preparation, J.A., L.A.O., E.E.; writing—review and editing, J.A., L.A.O., D.I.-M., E.E., L.G.-C.; visualization, J.A., L.A.O., E.E.; supervision, J.A., L.A.O.; project administration, L.A.O.; funding acquisition, J.A. All authors have read and agreed to the published version of the manuscript.

Funding: This research was funded the Fondo Sectorial de Investigación Ambiental SEMARNATCONACYT 2015 through project 262970, the Universidad Nacional Autónoma de México DGAPA/PAPIIT through projects IN105009 and ES209301, and Programa de Investigación en Cambio Climático (PINCC 2012-2014 and 2020-2021).

Institutional Review Board Statement: Not applicable.

Informed Consent Statement: Not applicable.

Data Availability Statement: Data are available from the authors upon reasonable request.

Acknowledgments: The Comisión Estatal de Parques Naturales y de la Fauna (CEPANAF, Secretaría de Ecología, Gobierno del Estado de México) provided the permit for scientific research at the Área de Protección de Flora y Fauna Nevado de Toluca.

Conflicts of Interest: The authors certify that they have NO affiliations with or involvement in any organization or entity with any financial interest (such as honoraria; educational grants; participation in speakers' bureaus; membership, employment, consultancies, stock ownership, or other equity interest; and expert testimony or patent-licensing arrangements), or non-financial interest (such as personal or professional relationships, affiliations, knowledge or beliefs) in the subject matter or materials discussed in this manuscript. 


\section{References}

1. Williamson, C.E.; Dodds, W.; Kratz, T.K.; Palmer, M.A. Lakes and streams as sentinels of environmental change in terrestrial and atmospheric processes. Front. Ecol. Environ. 2008, 6, 247-254. [CrossRef]

2. Adrian, R.; O’Reilly, C.M.; Zagarese, H.; Baines, S.B.; Hessen, D.O.; Keller, W.; Livingstone, D.M.; Sommaruga, R.; Straile, D.; Van Donk, E.; et al. Lakes as sentinels of climate change. Limnol. Oceanogr. 2009, 54, 2283-2297. [CrossRef]

3. Tranvik, L.J.; Downing, J.A.; Cotner, J.B.; Loiselle, S.A.; Striegl, R.G.; Ballatore, T.J.; Dillon, P.; Finlay, K.; Fortino, K.; Knoll, L.B.; et al. Lakes and reservoirs as regulators of carbon cycling and climate. Limnol. Oceanogr. 2009, 54, 2298-2314. [CrossRef]

4. Williamson, C.E.; Saros, J.E.; Vincent, W.F.; Smol, J.P. Lakes and reservoirs as sentinels, integrators, and regulators of climate change. Limnol. Oceanogr. 2009, 54, 2273-2282. [CrossRef]

5. Catalan, J.; Rondón, D. Perspectives for an integrated understanding of tropical and temperate high-mountain lakes. J. Limnol. 2016, 75, 215-234. [CrossRef]

6. Boggero, A.; Barbieri, A.; De Jong, J.; Marchetto, A.; Mosello, R. Chemistry and critical loads of Alpine lakes in Canton Ticino (Southern Central Alps). Aquat. Sci. 1998, 60, 300-315. [CrossRef]

7. Curtis, C.J.; Barbieri, A.; Camarero, L.; Gabathuler, M.; Galas, J.; Hanselmann, K.; Kopacek, J.; Mosello, R.; Nickus, U.; Rose, N.; et al. Application of static critical load models for acidity to high mountain lakes in Europe. Water Air Soil Pollut. 2002, 2, 115-126. [CrossRef]

8. Marchetto, A.; Mosello, R.; Psenner, R.; Barbieri, A.; Bendetta, G.; Tait, D.; Tartari, G.A. Evaluation of the level of acidification and the critical loads for Alpine lakes. Ambio 1994, 23, 150-154.

9. Pastorino, P.; Prearo, M. High-mountain lakes, indicators of global change: Ecological characterization and environmental pressures. Diversity 2020, 12, 260. [CrossRef]

10. Payne, A.I. The Ecology of Tropical Lakes and Rivers, 1st ed.; Wiley: New York, NY, USA, 1991; 310p, ISBN 0471905240.

11. Lewis, W.M. Tropical lakes: How latitude makes a diference. In Perspectives in Tropical Limnology; Schiemer, F., Boland, K.T., Eds.; SPB Academic Publishing bv: Amsterdam, The Netherlands, 1996; pp. 43-64.

12. Löffler, H. The limnology of tropical high-mountain lakes. Verh. Int. Ver. Theor. Angew. Limnol. 1964, 15, 176-193. [CrossRef]

13. Lewis, W.M.J. Radar image of one dimension rough surface with buried object. Lakes Reserv. Res. Manag. 2000, 5, 35-48. [CrossRef]

14. Aguilera, X.; Lazzaro, X.; Coronel, J.S. Tropical high-altitude Andean lakes located above the tree line attenuate UV-A radiation more strongly than typical temperate alpine lakes. Photochem. Photobiol. Sci. 2013, 12, 1649-1657. [CrossRef]

15. Eggermont, H.; Russell, J.M.; Schettler, G.; Van Damme, K.; Bessems, I.; Verschuren, D. Physical and chemical limnology of alpine lakes and pools in the Rwenzori Mountains (Uganda-DR Congo). Hydrobiologia 2007, 592, 151-173. [CrossRef]

16. Fetahi, T.; Mengistou, S.; Schagerl, M. Zooplankton community structure and ecology of the tropical-highland Lake Hayq, Ethiopia. Limnologica 2011, 41, 389-397. [CrossRef]

17. Rietti-Shati, M.; Yam, R.; Karlen, W.; Shemesh, A. Stable isotope composition of tropical high-attitude fresh-waters on Mt. Kenya, Equatorial East Africa. Chem. Geol. 2000, 166, 341-350. [CrossRef]

18. Löffler, H. Contribution to the Limnology of High Montain Lakes in Central America. Int. Rev. Gesamten Hydrobiol. Hydrogr. 1972, 57, 397-408. [CrossRef]

19. Rivera-R., C.; Solano-M., D.; Zapata-A., A.; Donato-R., J. Phytoplankton diversity in a tropical high mountain lake. Verh. Int. Ver. Theor. Angew. Limnol. 2005, 29, 418-421. [CrossRef]

20. Widmer, C.; Kittel, T.; Richerson, P.J. A survey of the biological limnology of Lake Titicaca. Verh. Int. Ver. Theor. Angew. Limnol. 1975, 19, 1504-1510. [CrossRef]

21. Huamán, P.; Mariano, M.; Chanco, M.; Montoya, H. Estructura del Macrobentos de la laguna de Paca, Junin. Rev. Peru. Biol. 2002, 9, 29-38. [CrossRef]

22. Tapia, L.; Sánchez, T.; Baylón, M.; Jara, E.; Arteaga, C.; Maceda, D.; Salvatierra, A. Invertebrados bentónicos como bioindicadores de calidad de agua en Lagunas Altoandinas del Perú. Ecol. Apl. 2018, 17, 149-163. [CrossRef]

23. Alcocer, J.; Oseguera, L.A.; Escobar, E.; Peralta, L.; Lugo, A. Biomass and Water in Two Phytoplankton Chemistry in Central Lakes Mexico Tropical. Artic Antart. Alp. Res. 2004, 36, 342-346. [CrossRef]

24. García-Palomo, A.; Macías, J.L.; Arce, J.L.; Capra, L.; Garduño, V.H.; Espíndola, J.M. Geology of Nevado de Toluca Volcano and surrounding areas, central Mexico. Geol. Soc. Am. Map Chart Ser. 2002, MCH089, 1-26.

25. Bloomfield, K.; Valastro, S. Late Pleistocene Eruptive History of Nevado de Toluca Volcano, Central Mexico. Bull. Volcanol. 1974, 85, 901-906. [CrossRef]

26. Alcocer, J.; Roberson, J.; Oseguera, L.A.; Lewis, W.M. Rhythmic episodes of heating and cooling control thermal stratification of two tropical high mountain lakes. Aquat. Sci. 2020, 82, 1-11. [CrossRef]

27. Folk, R.L. Petrology of Sedimentary Rocks; Hemphill Publishing Company: Austin, TX, USA, 1980.

28. Santisteban, J.I.; Mediavilla, R.; López-Pamo, E.; Dabrio, C.J.; Ruiz, Z.M.B.; Gil, G.M.J.; Silvino, C.; Martínez-Alfaro, P.E. Loss on ignition: A qualitative or quantitative method for organic matter and carbonate mineral content in sediments? J. Paleolimnol. 2004, 32, 287-299. [CrossRef]

29. Wetzel, R.G. Limnology: Lake and River Escosystems, 3rd ed.; Elsevier Science: San Diego, CA, USA, 2001; 1006p.

30. Rice, E.W.; Baird, R.B.; Eaton, A.D. (Eds.) Standar Methods for the Examination of Water and Wastewater; AWWA: New York, NY, USA, 2017; 1193p.

31. Ward, H.B.; Whipple, G.C. Fresh-Water Biology, 2nd ed.; Edmondson, W.T., Ed.; John Wiley \& Sons.: New York, NY, USA, 1959. 
32. Merritt, R.; Cummins, K.; Berg, M.B. An Introduction to the Aquatic Insects of North America, 5th ed.; Kendall Hunt Pub Co: Dubuque, IA, USA, 2019; 1498p.

33. Pennak, R.W. Fresh-Water Invertebrates of the United States; John Wiley \& Sons: New York, NY, USA, 1978.

34. Throp, J.H.; Covich, A.P. Ecology and Classification of North American Freshwater Invertebrates; Academic Press: Cambridge, MA, USA, 1991.

35. Brinkhurst, R.O.; Marchese, R.M. Guía Para la Identificación de Oligoquetos Acuáticos Continentales de Sud y Centroamerica, 2nd ed.; Asociación Ciencias Naturales del Litoral: Santa Fe, Argentina, 1992.

36. Hiltunen, J.K.; Klemm, D.J. A Guide to the Nadidae (Annelida: Clitellata: Oligochaeta) of North America; EPA: Cincinnati, OH, USA, 1980; 64p.

37. Stimpson, K.; Donald, J.K.; Hiltunen, J. A Guide to the Freshwater Tubificidae (Annelida: Clitellata: Oligochaeta) of North America; Environmental Monitoring and Support Laboratory, Office of Research and Development, US Environmental Protection Agency: Washington, DC, USA, 1982; 70p.

38. Mason, W.T.J. An Introduction to the Identification of Chironomid Larvae; U.S. Environmental Protection Agency: Cincinnati, OH, USA, 1973; 96p.

39. Wiederholm, T. Chironomidae of the Holarctic Region: Keys and Diagnoses; Entomological Society of Lund: Lund, Sweden, 1989; 457p.

40. Moreno, J.; Massaferro, J.; Caballero, M.; Oseguera, L. First record of the Pseudodiamesa branickii species-group (Diptera: Chironomidae: Diamesinae) from central Mexico. Rev. Mex. Biodivers. 2020, 91, 1-6. [CrossRef]

41. Margalef, R. Limnología; Ediciones Omega, S.A.: Barcelona, Spain, 1983; 1010p.

42. Weber, C.I. Biological Field and Laboratory Methods for Measuring the Quality of Surface Water and Effluents; National Environmental Research Center, Office of Research and Development, US Environmental Protection Agency: Cincinnati, OH, USA, 1973; 231p.

43. IPCC. Climate Change 2013: The Physical Science Basis. Contribution of Working Group I to the Fifth Assessment Report of the Intergovernmental Panel on Climate Change; IPCC: Cambridge, UK; New York, NY, USA, 2013; 1585p.

44. Hock, R.; Rasul, G.; Adler, C.; Cáceres, B.; Gruber, S.; Hirabayashi, Y.; Jackson, M.; Kääb, A.; Kang, S.; Kutuzov, S.; et al. High Mountain Areas. In IPCC Special Report on the Ocean and Cryosphere in a Changing Climate; Pörtner, H.-O., Roberts, D.C., Masson-Delmotte, V., Zhai, P., Tignor, M., Poloczanska, E., Mintenbeck, K., Alegría, A., Nicolai, M., Okem, A., et al., Eds.; Paris, France, 2019, in press. Available online: https:/ /www.ipcc.ch/srocc/ (accessed on 28 April 2021).

45. Held, I.M.; Soden, B.J. Robust responses of the Sahelian hydrological cycle to global warming. J. Clim. 2006, 19, 5686-5699. [CrossRef]

46. Williamson, C.E.; Saros, J.E.; Schindler, D.W. Climate change: Sentinels of change. Science 2009, 323, 887-888. [CrossRef]

47. Wuebbles, D.J.; Easterling, D.R.; Hayhoe, K.; Knutson, T.; Kopp, R.E.; Kossin, J.P.; Kunkel, K.E.; LeGrande, A.N.; Mears, C.; Sweet, W.V.; et al. Our globally changing climate. In Climate Science Special Report: Fourth National Climate Assessment; Webbles, D.J., Fahey, D.W., Hibbard, K.A., Dokken, D.J., Stewart, B.C., Maycock, T.K., Eds.; U.S. Global Change Research Program: Washington, DC, USA, 2017; Volume I, pp. 35-72.

48. Charles, D.F. Effects of acidic deposition on North American lakes: Palaeolimnological evidence from diatoms and chrysophytes. Philos. Trans.-R. Soc. Lond. B 1990, 327, 403-412. [CrossRef]

49. Mosello, R.; Marchetto, A.; Boggero, A.; Brizzio, M.C.; Tartari, G.A.; Rogora, M. Pluriannual evolution of the hydrochemistry of two Alpine lakes (Lake Paione Inferiore and Lake Paione Superiore, Ossola Valley) in relation to atmospheric loads. J. Limnol. 1999, 58, 42-48. [CrossRef]

50. Roy, K.M.; Dukett, J.; Houck, N.; Lawrence, G.B. A Long-Term Monitoring Program for Evaluating Changes in Water Quality in Selected Adirondack Waters; New York State Energy Research and Development Authority: New York, NY, USA, 2012; 43p.

51. Driscoll, C.T.; Driscoll, K.M.; Roy, K.M.; Mitchell, M.J. Chemical response of lakes in the Adirondack Region of New York to declines in acidic deposition. Environ. Sci. Technol. 2003, 37, 2036-2042. [CrossRef]

52. Henriksen, A.; Joranger, E.; Semb, A. The Contribution of Nitrogen to Acidification; The National Environmental Monitoring Programme Report 408/90; State Pollution Control Authority: Oslo, Norway, 1990.

53. Marchetto, A.; Mosello, R.; Rogora, M.; Manca, M.; Boggero, A.; Morabito, G.; Musazzi, S.; Tartari, G.A.; Nocentini, A.M.; Pugnetti, A.; et al. The chemical and biological response of two remote mountain lakes in the Southern Central Alps (Italy) to twenty years of changing physical and chemical climate. J. Limnol. 2004, 63, 77-89. [CrossRef]

54. Rogora, M.; Marchetto, A.; Mosello, R. Trends in the chemistry of atmospheric deposition and surface waters in the Lake Maggiore catchment. Hydrol. Earth Syst. Sci. 2001, 5, 379-390. [CrossRef]

55. The MOLAR water Chemistry Group The MOLAR project: Atmospheric deposition and lake water chemistry. J. Limnol. 1999, 58, 88-106. [CrossRef]

56. Ibarra-Morales, D.; Alcocer, J.; Oseguera, L.A.; Sosa-Echeverría, R. Bulk Deposition and Main Ionic Composition in a Remote Tropical Region: Nevado de Toluca, Mexico. Water Air Soil Pollut. 2020, 231, 413, 1-13. [CrossRef]

57. Rieradevall, M.; Jiménez, M.; Prat, N. The zoobenthos of six remote high mountain lakes in Spain and Portugal. Verh. Int. Ver. Theor. Angew. Limnol. 1998, 26, 2132-2136. [CrossRef]

58. Kownacki, A.; Galas, J.; Dumnicka, E.; Mielewczyk, S. Invertebrate communities in permanent and temporary high mountain lakes (Tatra Mts). Ann. Limnol. 2000, 36, 181-188. [CrossRef]

59. Hamerlík, L.; Svitok, M.; Novikmec, M.; Očadlík, M.; Bitušík, P. Local, among-site, and regional diversity patterns of benthic macroinvertebrates in high altitude waterbodies: Do ponds differ from lakes? Hydrobiologia 2014, 723, 41-52. [CrossRef] 
60. Füreder, L.; Ettinger, R.; Boggero, A.; Thaler, B.; Thies, H. Macroinvertebrate diversity in Alpine lakes: Effects of altitude and catchment properties. Hydrobiologia 2006, 562, 123-144. [CrossRef]

61. Catalan, J.; Camarero, L.; Felip, M.; Pla, S.; Ventura, M.; Buchaca, T.; Bartumeus, F.; De Mendoza, G.; Miró, A.; Casamayor, E.O.; et al. High mountain lakes: Extreme habitats and witnesses of environmental changes. Limnetica 2006, 25, 551-584.

62. Krno, I.; Šporka, F.; Galas, J.; Hamerlík, L.; Zat'ovičová, Z.; Bitušík, P. Littoral benthic macroinvertebrates of mountain lakes in the Tatra Mountains (Slovakia, Poland). Biologia 2006, 61, S147-S166. [CrossRef]

63. Steingruber, S.M.; Boggero, A.; Caissutti, C.P.; Dumnicka, E.; Colombo, L. Can we use macroinvertebrates as indicators of acidification of high-altitude Alpine lakes? Boll. Della Soc. Ticin. Sci. Nat. 2013, 101, 23-34.

64. Allard, M.; Moreau, G. Effects of experimental acidification on a lotic macroinvertebrate community. Hidrobiologia 1987, 144, 37-49. [CrossRef]

65. Collins, N.C.; Zimmerman, A.P.; Knoechel, R. Comparisons of benthic infauna and epifauna biomasses in acidified and nonacidified Ontario lakes. In Proceedings of the Effects of Acidic Precipitation on Benthos; Singer, R., Ed.; The North American Benthological Society: Hamilton, NY, USA, 1980; pp. 35-48.

66. Vrba, J.; Bojková, J.; Chvojka, P.; Fott, J.; Kopáček, J.; Macek, M.; Nedbalová, L.; Papáček, M.; Rádková, V.; Sacherová, V.; et al. Constraints on the biological recovery of the Bohemian Forest lakes from acid stress. Freshw. Biol. 2016, 61, 376-395. [CrossRef]

67. Dermott, R.M. Benthic fauna in a series of lakes displaying a gradient of pH. Hydrobiologia 1985, 128, 31-38. [CrossRef]

68. Barmuta, L.A.; Cooper, S.D.; Hamilton, S.K.; Kratz, K.W.; Melack, J.M. Responses of zooplankton and zoobenthos to experimental acidification in a high-elevation lake (Sierra Nevada, California, U.S.A.). Freshw. Biol. 1990, 23, 571-586. [CrossRef]

69. Vranovský, M.; Krno, I.; Šporka, F.; Tomajka, J. The effect of anthropogenic acidification on the hydrofauna of the lakes of the West Tatra Mountains (Slovakia). Hydrobiologia 1994, 274, 163-170. [CrossRef] 